\title{
HAEMOLYTIC DISEASE OF THE NEWBORN DUE TO ANTI-DUFFY (Fy)
}

\author{
BY

\section{J. B. BAKER, DAVID GREWAR, MARION LEWIS, HIROKO AYUKAWA and BRUCE CHOWN} \\ From the Department of Paediatrics, University of Manitoba, Winnipeg, and the Blood Group Reference and Research \\ Laboratory, Children's Hospital, Winnipeg, Canada
}

(RECEIVE FOR PUBLKATION MARCH 20, 1956)

So far as we know haemolytic disease of the newborn due to anti-Duffy $\left(F y^{\circ}\right)$ has not been reported. Race and Sanger (1954) say that no well authenticated case had been reported up to the time of publication of their book, while no such case is listed in the Current List of Medical Literature from 1951 to date. The following one is therefore placed on record.

\section{Case Report}

Mrs. Vall is group $\mathbf{O}, \mathbf{R h}$-negative, Duffy-negative; her husband, group $\mathbf{O}, \mathbf{R h}$-negative, Duffy-positive. Mr. Vall is $\mathbf{O}$; MsNs; $\mathbf{P}+$; cdE.cde; kk; Fy $(\mathbf{a}+)$; Le(a-). Mrs. Vall is $\mathbf{O}$; NsNs; $\mathbf{P}+$; cde.cde; Kk; Fy(a-); Le(a-); Jk(a+). Baby is $\mathbf{O}$; NsNs; $\mathbf{P}+$; cde.cde; kk; Fy $(a+)$; Le(a-). Mrs. Vall's pregnancy record is as follows:

(1) In 1949, normal. The mother was transfused immediately following this delivery, which was complicated, and two weeks later she received another blood transfusion. There was no clinically adverse reaction following either transfusion.

(2) In 1952, anencephalic foetus.

(3) In 1953, six months' gestation stillbirth.

(4) In 1955, the present baby, a girl, was born at term on December 19, weighing $5 \mathrm{lb}$. $6 \mathrm{oz}$. The baby's colour appeared normal at birth. Jaundice was first noticed when she was 12 hours old. About the same time she began to pass brownish-red blood by rectum and to vomit swallowed blood. The jaundioe deepened, and at 38 hours she was admitted to the Children's Hospital, Winnipeg. Her general condition was good. There was marked jaundice and a congenital anomaly of the thoracic spine was apparent, but there were no other notable findings on physical examination. The haemoglobin was 16 g.; reticulocytes $13 \cdot 2 \%$; total nucleated red cells $1,188 / \mathrm{c} . \mathrm{mm}$; serum bilirubin, direct acting $0.5 \mathrm{mg}$., total $13.7 \mathrm{mg}$. \%. The infant's blood grouping was $\mathbf{O}$, Rh-negative, Duffy-positive. The direct Coombs test was positive, the reaction, however, being weaker than that usually seen in $\mathrm{Rh}$ sensitization of any clinical degree.
Immediate replacement transfusion was deemed unnecessary. The blood passed per rectum was shown by the alkali denaturation test to be adult blood which the foetus had swallowed in utero.

The bilirubin level continued to rise, being $18.7 \mathrm{mg}$. at 52 hours and $21 \mathrm{mg}$. at 76 hours. At this point, fearing the possibility of kernikterus, a replacement transfusion was done, using blood that was Vall-negative, Fy $(\mathrm{a}-)$. The bilirubin was reduced thereby to $13 \cdot 3 \mathrm{mg}$.; rose slowly to a peak of $22.8 \mathrm{mg}$. at 114 hours, then fell, reaching $10.8 \mathrm{mg}$. at 212 hours. The jaundice was gone by the fifteenth day and the baby was discharged, apparently well save for the congenital anomaly of the spine. Radiographs showed the latter to be a hemivertebral formation extending from $\mathrm{C7}$ to $\mathrm{T8}$.

The diagnosis of haemolytic disease seems certain: the jaundice beginning within 12 hours of birth and progressing, the steady and marked rise in serum bilirubin, the high reticulocyte and normoblast count, and the positive direct Coombs test of the baby's blood on both days 2 and 4 . The mother's serum did not react by the standard saline, trypsin saline or albumin methods with any group $\mathbf{O}$ cells, or by the indirect Coombs or trypsin indirect Coombs methods with cells that were Fy(a-) but contained the following antigens absent from her cells: M, C, C*, D, E, Jkb. Her serum did react strongly by the standard indirect Coombs method and weakly by the trypsin indirect Coombs method with her husband's cells and with eight other Fy $(\mathrm{a}+)$ cells but not with seven Fy(a-) cells. The antibody is anti-Fy"; the titre was 8.

The Canadian Red Cross Blood Transfusion Service provided 10 samples of group $\mathrm{O}$, Rh-negative blood from which a suitable donor was selected by an indirect Coombs cross-match with the mother's serum and by Duffy typing. No anti-Fys could be demonstrated in the baby's serum by saline, albumin or the indirect Coombs test, nor were we able to elute an antibody from the baby's cells taken at the start of the replacement transfusion on the fourth day; the direct Coombs reaction, however, was still positive at that time.

The mother was most probably sensitized by one or other of the earlier transfusions but we have so far been 
unable to trace the donors. The other, but less likely, explanation would be from isoimmunization consequent on the father being Duffy-positive.

\section{Summary}

The fourth child of a woman who had had two transfusions six years earlier developed haemolytic disease of the newborn. The father and baby were
Duffy-positive $[F y(a+)]$, the mother, Duffy-negative [Fy $(\mathrm{a}-)$ ]. The mother's serum contained anti-Duffy (anti-Fy) and no other demonstrable antibody. The baby was successfully treated by replacement transfusion with Duffy-negative [Fy(a-)] blood.

Refenence

Race, R. R. and Sanger, Ruth (1954). Blood Groups in Man, 2nd ed. Oxford. 